\title{
Productivity Response to Plant Density in Five Sorghum bicolor Varieties in Dry Environments
}

\author{
M. M. Rady and A. A. A. Mekdad* \\ Botany Department and *Agronomy Department, Faculty of \\ Agriculture, Fayoum Univ., 63514 Fayoum, Egypt.
}

\begin{abstract}
RY LAND characterizes by low fertility and poor structure. For sustainable agriculture, it needs some technologies application such as suitable variety and plant density for crop management to enhance crop performance. For studying yield behavior under such conditions, two field trials were conducted using five sweet sorghum varieties (Brandes; $\mathrm{V}_{1}$, Honey; $\mathrm{V}_{2}$, GkÁron; $\mathrm{V}_{3}$, Róna $1 ; \mathrm{V}_{4}$ and GK Csaba; $\mathrm{V}_{5}$ ) and three plant densities $\left(111000 ; \mathrm{D}_{1}, 133000 ; \mathrm{D}_{2}\right.$ and $166000 ; \mathrm{D}_{3}$ plants $\left.\mathrm{ha}^{-1}\right)$. Results indicated that all varieties differed significantly in all tested parameters; growth, juice quality and yield and its components. Of all investigated varieties, the most productive was $\mathrm{V}_{1}$, while $\mathrm{V}_{5}$ was the least. Ethanol yield was recorded highest values with $\mathrm{V}_{1}$ over two seasons. On the other side, $\mathrm{V}_{5}$ flowered 25 days earlier than $\mathrm{V}_{1}$. Time of $50 \%$ flowering and yields were increased with increasing plant density. The integrated $\mathrm{V}_{1} \times \mathrm{D}_{3}$ was found to be the best treatment generating highest ethanol (biofuel), yields and seed index in 2013 and 2014 season. Therefore, this integrated treatment is recommended for dry environments.
\end{abstract}

Keywords: Sweet Sorghum, Varieties plant density, Yield and quality, Dryland

Sorghum is one of the resilient crops. It grows well under environmental stresses such as drought. In more arid areas, it could replace maize as a biofuel feedstock. It has the ability to grow in the areas that non-efficiently productive with maize or soybean. Probably because of its African origins and its extensive root system, sorghum tolerates drought better than other $\mathrm{C}_{4}$ crops, as well as it also tolerates low levels of soil salinity better than corn and sugarcane (Almodares \& Hadi, 2009).

In arid and semi-arid environments including Egypt, limited rainfall and low soil fertility have reduced crop productivity, particularly sugar cane crop that produces about $63 \%$ of sugar production worldwide with high water (20000$24000 \mathrm{~m}^{3}$ irrigation water/ha) and soil fertility requirements (Singh et al., 2008). Sweet sorghum (Sorghum bicolor L., Moench) is well adapted to the semiarid tropics, having more water use efficiency $\left(310 \mathrm{~kg}\right.$ water $\mathrm{kg}^{-1}$ dry matter) compared to maize ( $370 \mathrm{~kg}$ water $\mathrm{kg}^{-1}$ dry matter). Using low water quantity, it converts atmospheric $\mathrm{CO}_{2}$ into sugars to be the most promising bio-energy crop (Reddy et al., 2007). Sweet sorghum with its high sugar content, wide adaptability and low water requirements is being considered as a potential alternative source 
of biomass energy (Keeney \& Deluca, 1992). It is required for reclaimed dry areas due to its ability to grow and produce well in such areas. In addition, ethanol produced from sweet sorghum has superior burning quality, with high octane rating and less sulphur emission (Ture et al., 1997).

Proper soil, water management, and selection of suitable varieties severely affect crop productivity and soil sustainability (Benlhabib et al., 2014 and Mekdad \& Rady, 2016). Productivity and its quality of sweet sorghum are affected greatly by many factors such as variety selection that is one of the most important decisions to produce the sweet sorghum syrup. Varieties of sweet sorghum are varied greatly in stalk height, diameter, syrup production and yield and its quality (Mohamed et al., 2006). Furthermore, Aly et al. (2008) reported that sweet sorghum varieties show significant differences in leaf area, plant height and diameter, and the contents of total soluble solids and sucrose. They are differed also in the percentages of purity, juice and syrup extraction, and the yields of stripped stalks, juice and syrup.

A variety with a high stalk yield, lodging resistance, high percentage of extractable juice and high brix content, coupled with resistance to diseases and drought is preferred for biofuel and biomass production (Morris, 2006 and Wang et al., 2016). It has been found that sweet sorghum varieties were differed widely in their potential production of ethanol (Davila-Gomez et al., 2011). The full potential of crop can be exploited by applying optimum agronomic practices, among them plant density that possess an effect on sweet sorghum productivities. It has been observed that increasing plant density increased juice extraction percentage and stalks yield. Plant density of about 166,000 plants ha ${ }^{-1}$ generated the highest values of plant height and stalk yield, however stalk diameter, leaf area, total soluble solids percentage, sucrose percentage, purity percentage and sugar yield resulted from the plant density of about 83,000 plants ha $^{-1}$ (Abo El-Wafa \& Abo El-Hamd, 2001 and Bekheet et al., 2006).

The main objective of this work was to analyze a typical management of sweet sorghum cultivation in relation to varieties and plant densities under dry region conditions including Egypt. The sustainable cropping technique of some plant densities was assessed to detect and identify the suitable variety that possess the best biofuel, sugar and grain yields and their qualities using five varieties of sweet sorghum over two seasons.

\section{Materials and Methods}

Two field experiments were conducted at the Experimental Farm of the Faculty of Agriculture (Southeast Fayoum; 30 $\left.54^{\prime} 55^{\prime \prime} \mathrm{E} 29^{\circ} 17^{\prime} 06^{\prime \prime} \mathrm{N}\right)$, Egypt. The soil used for this study was sandy loam. It possesses $0.78 \%$ organic matter, 5.33 $\mathrm{dSm}^{-1}$ electrical conductivity and $\mathrm{pH}$ of 7.87 as an average of the soil analyses for 2013 and 2014 summer seasons according to Black et al. (1965) and Jackson (1973). Electrical conductivity $\left(\mathrm{EC}_{\mathrm{e}}\right)$ was measured using a soil paste extract. The average of $\mathrm{EC}_{\mathrm{e}}$ value $\left(5.33 \mathrm{dSm}^{-1}\right)$ classed the tested soils as being 
moderately saline according to Dahnke \& Whitney (1988). Daily temperatures ranged from $23.4-42.8{ }^{\circ} \mathrm{C}$ with an average of $33.1 \pm 4.2{ }^{\circ} \mathrm{C}$, and daily relative humidity ranged from $52.3-74.9 \%$ with an average of $63.6 \pm 3.6 \%$. Rainfall ranged from $2-10 \mathrm{~mm}^{-1} \mathrm{yr}^{-1}$. These climatic data classed the region of this study as dry environment (FAO, 1976).

Three plant densities $\left[111000\left(\mathrm{D}_{1}\right), 133000\left(\mathrm{D}_{2}\right)\right.$ and $166000\left(\mathrm{D}_{3}\right)$ plants ha $\left.{ }^{-1}\right]$ were used in this study for five sweet sorghum varieties [i.e., Brandes $\left(\mathrm{V}_{1}\right)$, Honey $\left(\mathrm{V}_{2}\right)$, GkÁron $\left(\mathrm{V}_{3}\right)$, Róna $1\left(\mathrm{~V}_{4}\right)$ and GK Csaba $\left.\left(\mathrm{V}_{5}\right)\right]$. These plant densities were resulted from 30,25 and $20 \mathrm{~cm}$ plant spacing with two plants hill ${ }^{-1}$, respectively. Seeds of all varieties were purchased from the Field Crops Research Institute, Agricultural Research Center, Giza, Egypt. They were selected for uniformity by choosing those equal in size and like in color. The selected seeds were washed with distilled water, sterilized with a $1 \%$ sodium hypochlorite solution for two minutes and thoroughly washed again with distilled water, and left to air-dry. The seeds were sown on $25^{\text {th }}$ of May, 2013 and 2014 summer seasons and were harvested at dough to ripe stage in both seasons. Seedlings were thinned, to leave two plants hill ${ }^{-1}$, after 21 days from sowing. A split plot in randomized complete block design with three replications was used. Sweet sorghum varieties were arranged in the main plots, while plant densities were randomly distributed in the sub-plots. Each sub-plot area was 10.5 $\mathrm{m}^{2}$ ( $3 \mathrm{~m}$ width $\times 3.5 \mathrm{~m}$ length) and was consisted of five ridges with $60 \mathrm{~cm}$ wide. Fertilizers were applied as recommended by the Egyptian Ministry of Agriculture and Land Reclamation for sweet sorghum production in such region. Nitrogen fertilizer was added at a rate of $200 \mathrm{~kg} \mathrm{~N} \mathrm{ha}^{-1}$ in the form of ammonium nitrate $(33.5 \% \mathrm{~N})$ in two equal doses. The first dose was added at 30 days after sowing, and the second one was added 15 days later. During seed-bed preparation, phosphorus fertilizer was applied at a rate $40 \mathrm{~kg} \mathrm{P}_{2} \mathrm{O}_{5} \mathrm{ha}^{-1}$ in the form of calcium superphosphate $\left(15.5 \% \mathrm{P}_{2} \mathrm{O}_{5}\right)$. In addition, $120 \mathrm{~kg} \mathrm{~K}_{2} \mathrm{O}$ ha ${ }^{-1}$ was added in the form of potassium sulfate $\left(48 \% \mathrm{~K}_{2} \mathrm{O}\right)$ as for the $\mathrm{N}$ addition durations. Plots were irrigated based on the available water at $15-\mathrm{d}$ intervals. The all other recommended agricultural practices were carried out as recommended for sweet sorghum production.

Measurements of duration (days) to $50 \%$ flowering (anthesis) were recorded as the time from date of sowing to the time that $50 \%$ of the plants were extruded anthers in the mid-sections of the panicle (Vanderlip \& Reeves, 1972).

At harvest time, a random sample of twenty plants from each sub-plot was taken to assess growth traits. Leaf area, stem length, diameter and weight, leaf weight, panicle length diameter and weight, and seed index were recorded.

Juice quality traits were assessed using stalks that were taken from each subplot, stripped, cleaned and squeezed by electric roller pilot mill. Brix (\%) was estimated by using digital refractometer, sucrose (\%) was determined by using direct polarization method as described in the methods of AOAC (1995), purity 
(\%) was calculated [(sucrose $\% \div$ TSS\%) $\times 100]$, and juice extraction (\%) was determined as follows:

Juice extraction $(\%)=($ Juice weight $\div$ Stalk weight $) \times 100$.

Yield and its components were estimated as follows: Net stripped stalk, leaves, grain, sugar and juice yield, ethanol yield $\left(\mathrm{m}^{3} \mathrm{ha}^{-1}\right)$ were calculated according to the method described by Lipinski (1978):

Ethanol yield $=$ Sugar content $($ brix\% $) \times 6.5$ (converting index $) \times 0.85$ (producing index) $\times$ fresh biomass $\left(\mathrm{t} \mathrm{ha}^{-1}\right)$.

\section{Statistical analysis}

All obtained data were statistically analyzed by the technique of ANOVA for the split plot design using MSTAT-C (Michigan, USA), and LSD at 5\% and 1\% levels of probability was used to test the differences between treatment means.

\section{Results}

Results presented in Tables 1 and 2 revealed that the five sweet sorghum varieties significantly differed $(\mathrm{P} \leq 0.05)$ in all growth, juice quality and yield and its components. According to LSD, the Brandes variety exceeded the all other varieties for all studied traits, however, GK Csaba hybrid origin recorded the lowest values, except the parameter of days to $50 \%$ flowering, indicating that it was the fastest one in growth. It was noticed that planting the Brandes variety had a significant increases in leaf area, stem length and diameter, stem weight, leaf weight, panicle length and diameter, panicle weight, seed index, brix\%, sucrose $\%$, purity $\%$, juice extraction $\%$ from fresh stems, and yields in terms of stalk, leaves, grain, juice and sugar, as well as ethanol yield. These increases estimated by 55.1 and $28.1 \%, 84.6$ and $83.8 \%, 111.1$ and $111.6 \%$; 85.4 and $85.4 \%, 71.4$ and $71.4 \%, 34.0$ and $40.8 \%, 69.5$ and $79.8 \%, 96.3$ and $98.8 \%, 15.3$ and $18.3 \%, 7.9$ and $8.8 \%, 20.6$ and $19.2 \%, 11.8$ and $9.6 \%, 6.1$ and $7.1 \%, 55.5$ and $68.3 \%, 54.8$ and $54.5 \%, 170.6$ and $176.9 \%, 65.1$ and $80.1 \%, 78.6$ and $96.7 \%$, and 87.5 and $100.6 \%$ in the two growing seasons (2013 and 2014), respectively over to the hybrid GK Csaba variety of sweet sorghum.

Over both growing seasons, results in Tables 1 and 2 showed that, except ethanol yield, plant densities had a significant effects on time to $50 \%$ flowering (days), stem length, diameter and weight, panicle length, diameter and weight, leaves weight, seed index contents of brix and sucrose, purity percentage, juice extraction and yields in terms of stalk, leaves, grain, sugar and juice.

Plant densities exhibited significant positive effects on time of $50 \%$ flowering (days). Across varieties, the average days number to $50 \%$ flowering was higher (83.2 and 82.9) for the highest plant density $\left(166000\right.$ plants $\left.\mathrm{ha}^{-1} ; \mathrm{D}_{3}\right)$ compared to 80.1 and 79.6 days for the lowest plant density (111000 plants ha ${ }^{-1}$; $\mathrm{D}_{1}$ ) in both growing seasons, respectively. 
PRODUCTIVITY RESPONSE TO PLANT DENSITY.....

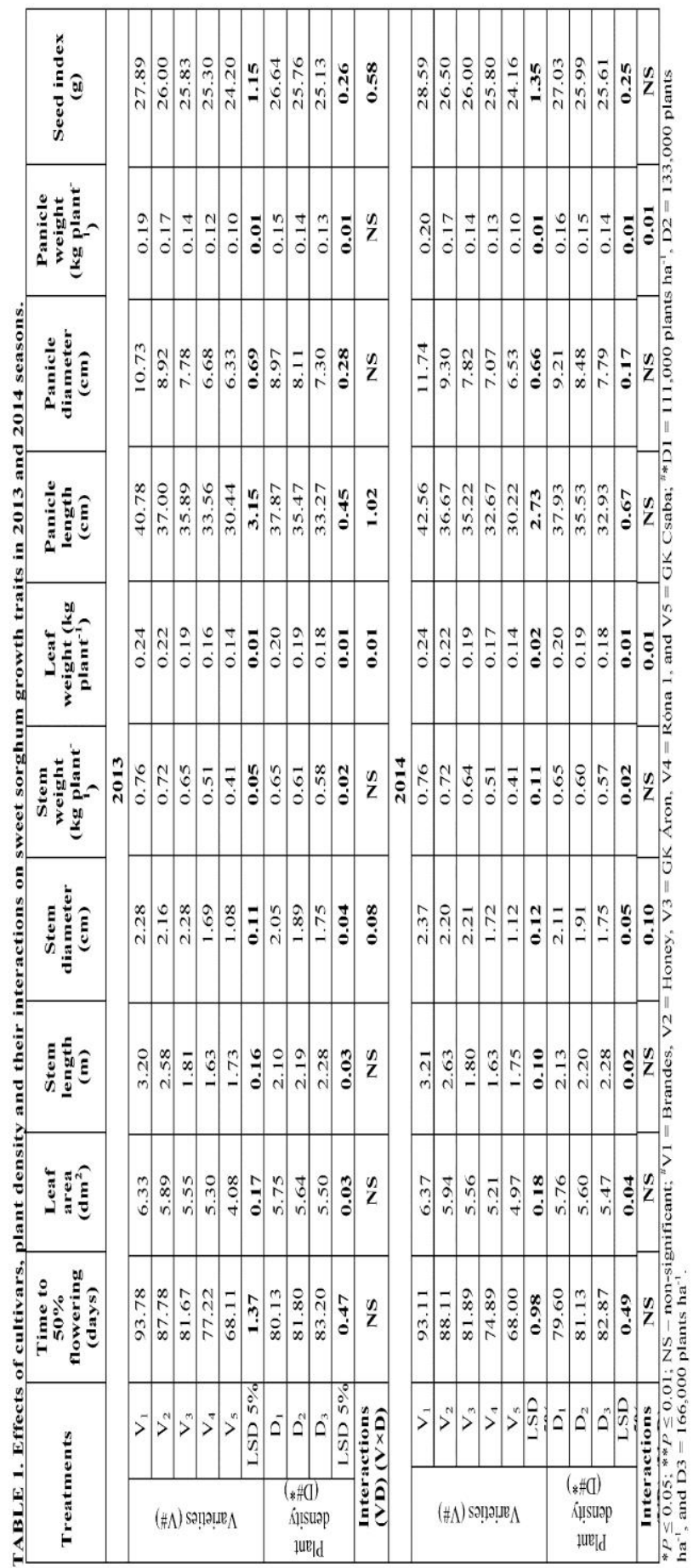

Egypt. J. Agron. Vol. 38, No. 3 (2016) 


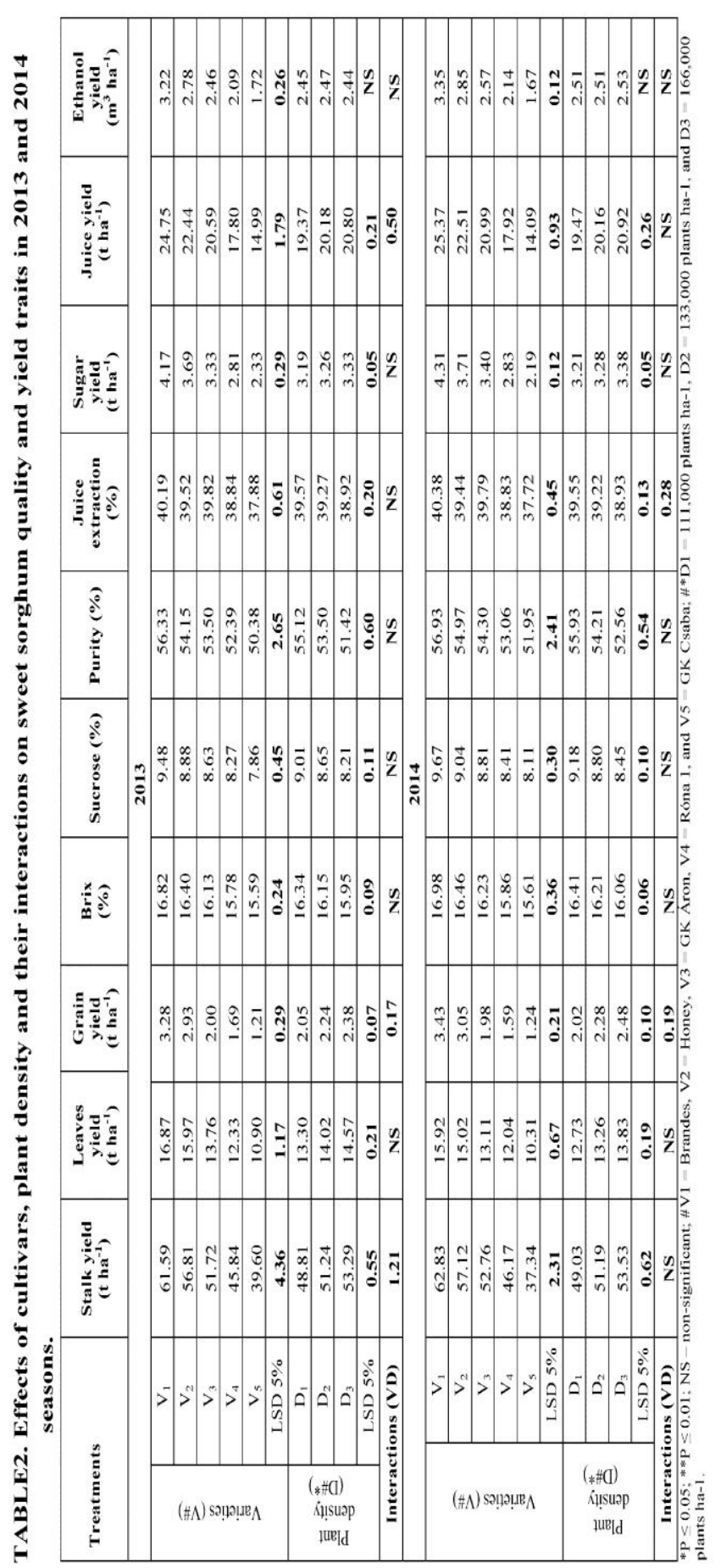

Egypt. J. Agron. Vol. 38, No. 3 (2016) 
Means of data obtained in Tables 1 and 2 showed that leaf area, stem diameter, stem weight, leaf weight, panicle length, diameter and weight, seed index, brix and sucrose contents, purity percentage and juice extraction from fresh stems were significantly decreased with increasing plant density from 111,000 to 166,000 plants ha ${ }^{-1}$. The highest plant density $\left(166,000\right.$ plants $\left.\mathrm{ha}^{-1}\right)$ recorded reductions of 4.5 and $5.1 \%, 14.6$ and $17.1 \%, 10.8$ and $12.3 \%, 10.0$ and $10.0 \%, 12.2$ and $13.2 \%, 18.6$ and $15.4 \%, 14.1$ and $13.5 \%, 5.7$ and $5.3 \%, 2.4$ and $2.1 \%, 8.9$ and $8.0 \%, 6.7$ and $6.0 \%$, and 1.6 and $1.6 \%$ over the lowest plant density $\left(111,000\right.$ plants ha $\left.{ }^{-1}\right)$ in both growing seasons, respectively.

It was noticed that the highest plant density of 166,000 plants ha $^{-1}$ had a significant increases in stem length $(\mathrm{cm})$, yields $\left(\mathrm{t} \mathrm{ha}^{-1}\right)$ in terms of stalks, leaves, grains, sugar and juice. These increases estimated by 8.7 and $7.2 \%, 9.2$ and $9.2 \%, 9.5$ and $8.6 \%, 16.3$ and $22.4 \%, 4.5$ and $5.2 \%$, and 7.4 and $7.5 \%$ in 2013 and 2014 seasons, respectively over the lowest plant density of 111,000 plants $\mathrm{ha}^{-1}$.

The interactions between varieties and plant densities were presented in Table 3 showed a significant effect for stem diameter, leaf weight and grain yield over both growing seasons. In addition, the values of panicle length, seed index, and stalks and juice yields were significant in the first season, while values of panicle weight and juice extraction from fresh stems were significant in the second season. The highest stem diameter $(2.5$ and $2.6 \mathrm{~cm})$, leaf weight $(0.26$ and $0.26 \mathrm{~kg} \mathrm{plant}^{-1}$ ) in the first and second season, respectively, panicle length $(44.00 \mathrm{~cm})$ in the first season, panicle weight $\left(0.22 \mathrm{~kg} \mathrm{plant}^{-1}\right)$ and juice extraction $(40.9 \%)$ in the second season were obtained by Brandes variety in combination with 111,000 plantha $^{-1}\left(\mathrm{~V}_{1} \times \mathrm{D}_{1}\right)$. However, the highest grain yield (3.64 and $\left.3.88 \mathrm{t} \mathrm{ha}^{-1}\right)$ in the first and second season, seed index $(29.6 \mathrm{~g})$, stalk yield $\left(65.0 \mathrm{tha}^{-1}\right)$ and juice yield $\left(25.9 \mathrm{tha}^{-1}\right)$ in the first season were obtained by Brandes variety in combination with 166,000 plant ha $^{-1}\left(\mathrm{~V}_{1} \times \mathrm{D}_{3}\right)$.

As shown in Table 4 the correlation coefficients between theoretical ethanol yield $\left(\mathrm{m}^{3} \mathrm{ha}^{-1}\right)$ and each of stalk yield $\left(\right.$ tha $\left.^{-1}\right)$, stalk weight $\left(\mathrm{kg} \mathrm{plant}^{-1}\right)$ and sucrose\% were computed to throw the light on the relationship of effectual traits importance. Positive and highly significant $(\mathrm{P} \leq 0.01)$ correlation coefficients were obtained between theoretical ethanol yield $\left(\mathrm{m}^{3} \mathrm{ha}^{-1}\right)$ and each of stalk yield $\left(0.96^{* *}\right.$ and $0.97^{* *}$, respectively), stalk weight $\left(0.93^{* *}\right.$ and $0.93^{* *}$, respectively) and sucrose $\%$ $\left(0.84^{* *}\right.$ and $0.84^{* *}$, respectively) in both growing seasons. In addition, positive and highly significant correlation coefficients were observed between stalk yield and stalk weight $\left(0.85^{* *}\right.$ and $0.87^{* *}$, respectively) and between stalk yield and sucrose $\%$ $\left(0.65^{* *}\right.$ and $0.70^{* *}$, respectively). It is noteworthy that, theoretical ethanol yield $\left(\mathrm{m}^{3} \mathrm{ha}^{-1}\right)$ showed the highest positive correlation with stalk yield and sucrose $\%$, indicating their economic importance. The results are shown in Table 5 clarify that there are three traits (i.e. sugar yield, purity percentage and juice extraction) in both 2013 and 2014 seasons were significantly $(\mathrm{P} \leq 0.001)$ contributed to variation in theoretical ethanol yield. 


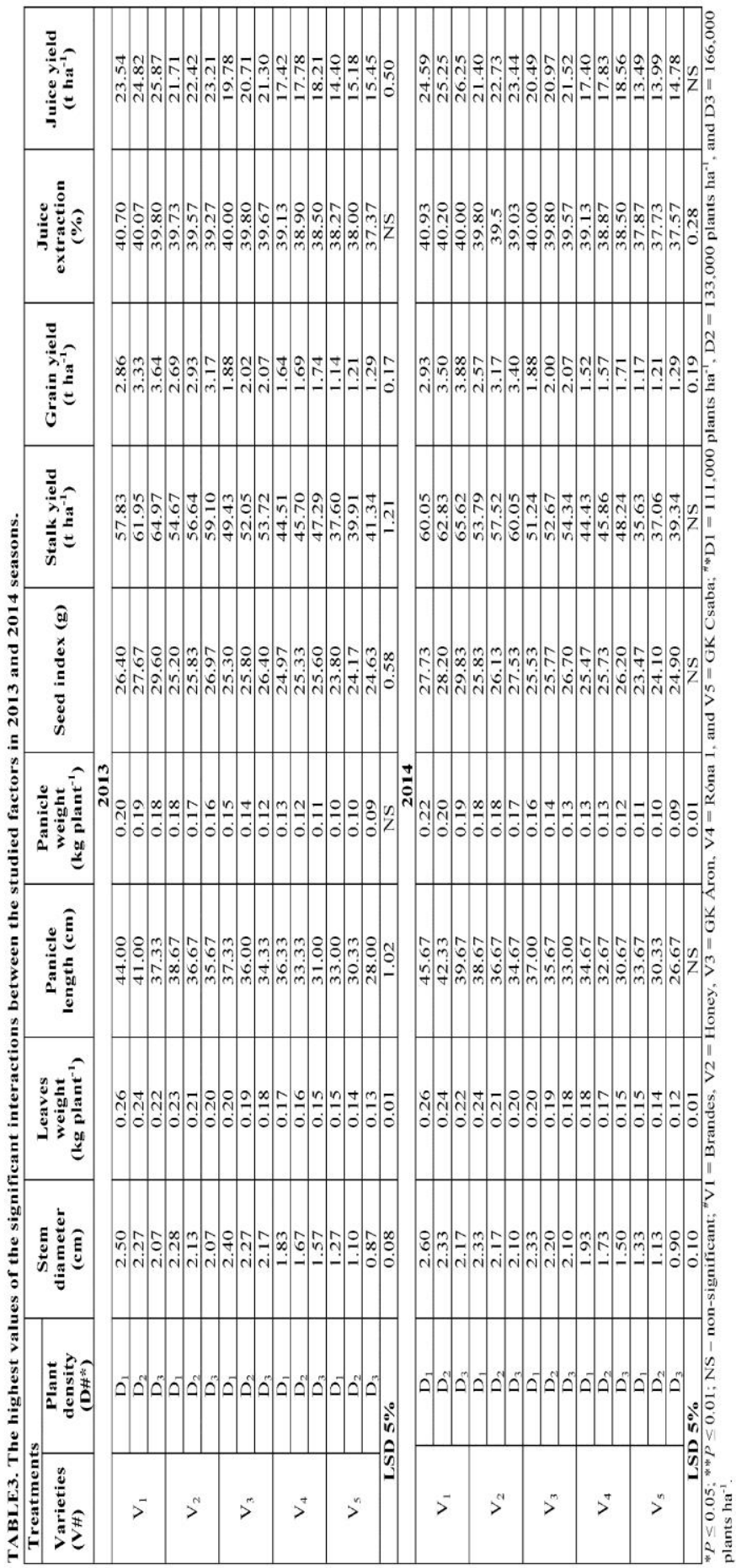

Egypt. J. Agron. Vol. 38, No. 3 (2016) 
TABLE 4. A matrix of simple correlation coefficient between theoretical ethanol yield and other important traits estimated in 2013 and 2014 seasons

\begin{tabular}{|l|c|c|c|c|c|}
\hline Characters & Seasons & $\mathbf{1}$ & $\mathbf{2}$ & $\mathbf{3}$ & $\mathbf{4}$ \\
\hline \multirow{2}{*}{$\begin{array}{l}\text { Theoretical ethanol yield } \\
\text { L fed }\end{array}$} & 2013 & 1 & & & \\
\hline & 2014 & 1 & & & \\
\hline \multirow{2}{*}{$2 . \quad$ Stalk yield t fed } & 2013 & $0.9604^{* *}$ & 1 & & \\
\hline \multirow{2}{*}{$3 . \quad$ Stalk weight kg } & 2014 & $0.9723^{* *}$ & 1 & & \\
\cline { 3 - 7 } & 2013 & $0.9252^{* *}$ & $0.8491^{* *}$ & 1 & \\
\hline \multirow{2}{*}{$4 . \quad$ Sucrose\% } & 2014 & $0.9313^{* *}$ & $0.8740^{* *}$ & 1 & \\
\cline { 3 - 7 } & 2013 & $0.8350^{* * *}$ & $0.6530^{* *}$ & $0.8711^{* *}$ & 1 \\
\hline & 2014 & $0.8443^{* *}$ & $0.6999^{* *}$ & $0.8832^{* *}$ & 1 \\
\hline
\end{tabular}

** Correlation coefficient is significant at $P \leq 0.01$.

TABLE 5. Correlation coefficient (r), coefficient of determination $\left(R^{2}\right)$ and standard error of the estimates (SEE) for predicting theoretical ethanol yield $\left(\mathrm{m}^{3} \mathrm{ha}^{-1}\right)$ in 2013 and 2014 seasons.

\begin{tabular}{|c|c|c|c|c|l|}
\hline Season & $\mathbf{r}$ & $\mathbf{R}^{2}$ & SEE & Significance & \multicolumn{1}{c|}{ Fitted equation } \\
\hline 2013 & 0.996 & 0.9992 & 6.81 & $* * *$ & $\begin{array}{l}\text { theoretical ethanol yield }=163.7+763.6 \text { sugar yield }+19.94 \\
\text { purity }-31.65 \text { juice extraction }\end{array}$ \\
\hline 2014 & 1.000 & 0.999 & 6.61 & $* * *$ & $\begin{array}{l}\text { theoretical ethanol yield }=56.19+772.69 \text { sugar yield }+19.14 \\
\text { purity }-28.169 \text { juice extraction }\end{array}$ \\
\hline
\end{tabular}

\section{Discussion}

Respond and adapt of varieties to dry environment and survive under low water availability are attained with various crops by the induction of various morphological, biochemical and physiological responses (Farooq et al., 2009). In the present study, the results indicated that Brandes variety was most tolerant to the adverse conditions of the study region, and was able to grow, flowering and gave economic yields with high qualities under suboptimal water supply compared to the all other tested varieties. On the other hand, the adverse conditions of the studied region may affect the plant water relations and cause specific and unspecific reactions, damage and adaptation reactions (Beck et al., 2007).

Time of days taken to $50 \%$ flowering ranged from 68 days for GK Csaba variety to 93 days for Brandes variety (Table 1). This indicated that GK Csaba variety (hybrid initiated from Sorghum bicolor $\times$ S. sudanense) was flowered 25 days earlier than Brandes variety. Therefore, the GK Csaba sweet sorghum variety can be used as forage crop, because it has a short growing period and can be harvested many times a year. Variation in phenology of sorghum varieties was also reported by Mahama (2012). In contrast, growth and quality values of Brandes variety were highest compared to the all other sweet sorghum varieties probably due to the genetic diversity. Sandeep et al. (2011) revealed that variety had significant influence on panicle length, 100-grain weight, grains per panicle and grain yield. Our results indicated that stem taller, thicker and heavier of sweet sorghum varieties could have higher stalks, grains, juice and sugar yields 
and, consequently, higher ethanol yield. Ethanol yield was ranged between $1.7-$ $3.4 \mathrm{~m}^{3} \mathrm{ha}^{-1}$ for hybrid GK Csaba and Brandes varieties in the first and second season, respectively, showing that Brandes variety was the highest productive and GK Csaba variety was the lowest productive among the all tested varieties. Meantime, the variations among sweet sorghum abilities in ethanol productions detected herein were affirmed previously by Abd El-Razek \& Besheit (2009).

To cope with low water availability, the most tolerant variety (Brandes) may initiate defense mechanisms, which need to be investigated in further details in such regions. Well performance of sweet sorghum, particularly Brandes variety under low water availability may be attained through plant escaping by shortening the life cycle or growing season, allowing plants to reproduce before the environment becomes dry. Flowering duration is an important trait in relation to low water adaptation, where a short life cycle can lead to low water escape (Araus et al., 2002). Dingkuhn \& Asch (1999) interactively determined the crop duration by genotype and the environment and also determined the ability of plants to escape from water shortage. Water stress escape occurs when phenological development is successfully matched with periods of soil moisture availability (Araus et al., 2002). Time of flowering is a major trait of a crop adaptation to the environment, particularly when the growing season is restricted by terminal drought and high temperatures. Turner et al. (2001) and Kavar et al. (2007) concluded that avoidance to water shortage consists of mechanisms that reduce water loss from plants. Reduction in water loss comes from stomatal control of transpiration, and also maintain water uptake through an extensive and prolific root system. In addition, Subbarao et al. (1995) and Turner et al. (2001) revealed that root characteristics such as biomass, length, density and depth are the main drought avoidance traits that contribute to final yield under dry environments. Sweet sorghum is characterized by extensive root system that enables plant to tolerate the adverse conditions (water shortage and high temperatures) of dry environments (Almodares \&Hadi, 2009). Kavar et al. (2007) showed that a deep and thick root system is helpful for extracting water from considerable depths. They added that where root system is the source to acquire water from soil, the root growth, proliferation, density and size are key responses of plants to low water availability. In addition, leaf pubescence and waxes/cuticles are xeromorphic traits that help to protect leaves from excessive heat load and reduced leaf temperatures and transpiration (Sandquist \& Ehleringer, 2003). Variety selection for a deep and extensive root system is one of the main strategies to increase crop productivity under moisture-deficit conditions as it can optimize the capacity to acquire water (Subbarao et al., 1995). Other mechanisms that may be found in sweet sorghum, particularly Brandes variety to tolerate low water availability in the studied region are osmotic adjustment, osmoprotection, antioxidation and a scavenging defense system. Another mechanism that emerged herein is the plant density. Data in the present study show that, the highest plant density $\left(166,000\right.$ plants $\left.^{-1} \mathrm{a}^{-1}\right)$ generated the highest yields and their qualities. This may be due to that the increase in plant density increased soil shading, and consequently reduced water evaporation with higher temperatures; however, the duration needed for the vegetative

Egypt. J. Agron. Vol. 38, No. 3 (2016) 
growth was delayed with increasing plant density. In this concern, Hamid \& Nasab (2001) concluded that the dense planting might have slightly slowly down the rate of plant development because of the more competition in higher plant densities. Lengthening the time for vegetative growth stage with increasing plant population has been also reported by Silva et al. (1999). Although highest yields and their qualities were obtained with the highest plant density, the highest values of growth traits were obtained with the lowest density $\left(111,000\right.$ plants $\left.\mathrm{ha}^{-1}\right)$. This may be resulted from more space, more availability to light and mineral nutrients and low interplants competition. Concerning, the reduction in vegetative traits accompanied with higher densities may be due to lower photosynthetic rate as a result of greater shading effect under higher densities. These results are in harmony with those reported by Mokadem (1994) and Mahmoud et al. (2013).It is noteworthy that the reduction in growth traits that accompanied with the highest plant density was compensated by producing highest yields of stalks, leaves, grains, sugar and juice. Similar results were obtained by Gutte et al. (2008) and Mahmoud et al. (2013).

The physiological basis of genetic variation in response to low water availability is not clear; in part, because more complicated mechanisms that have been suggested such as tissue water conservation, antioxidant defense system (enzymatic and non-enzymatic components), cell membrane stability, plant growth regulators, and compatible solutes (Farooq et al., 2009). In addition, under reduced soil water content, changes in gene expression (upand down-regulation) are concluded to occur. Various genes are induced to function in tolerance to water shortage (Kavar et al., 2007). With the studied region stress conditions, gene expression may be triggered directly. However, it is well established that tolerance to water shortage is a complex phenomenon involving the harmonized action of many genes (Agarwal et al., 2006 and Cattivelli et al., 2008).

Effects of water shortage stress in dry environments can be managed by production of the most appropriate plant genotypes/varieties together with adjustment of agronomic practices such as plant density. In the present study, the integrated Brandes variety $\times$ plant density of 166,000 plants ha $^{-1}$ found to be the best treatment, producing highest yields of biofuel, sugar and grains. Various important strategies to accomplish such objective of this study may entail generation of appropriate plant varieties and improvement of the existing high-yielding varieties taking in our minds the suitable plant densities. Efforts have been made to produce and select drought-tolerant varieties using the knowledge of responses of plants to drought stress and mechanisms involved. Away from this study, the most important strategies to such region under study may include selecting the desired varieties by conventional breeding using molecular and biotechnological means, including production of genetically modified or transgenic plants. In addition, inducing water stress tolerance in otherwise susceptible plants by priming and hormonal application may be used.

Egypt. J. Agron. Vol. 38, No. 3 (2016) 


\section{Conclusions}

It is evidenced that under dry environment conditions (low water availability and high temperatures), it is important to select a suitable variety to grow with a suitable plant density. The tested varieties differed significantly as a result of their varied response to the dry environment conditions, due to their different genetic background. There were changes in the growth, productivity and quality of the varieties accompanied with changes in plant density. Under the present study conditions, it could be recommended that using Brandes variety with applying the highest rate of plant density $\left(166,000\right.$ plant $\left.\mathrm{ha}^{-1}\right)$ is favorable integration that capable to accomplish acceptable profit from alcohol (biofuel),stalks, grains and juice yields of sweet sorghum.

\section{References}

A.O.A.C. (1995) "Official Methods of Analysis" Published by the A.O.A.C. Box 540, Washington.

Abd El-Razek, A.M. and Besheit, S.Y. (2009) Potential of some sweet sorghum (Sorghum bicolor L. Moench) varieties for syrup and ethanol production in Egypt. Sugar Tech.11 (3), 239-245.

Abo El-Wafa, A.M. and Abo El-Hamd, A.S. (2001) Evaluation of some sweet sorghum varieties under different plant populations in Upper Egypt. Minia Journal of Agricultural Research and Development, 21 (3), 475-492.

Agarwal, P.K., Agarwal, P., Reddy, M.K. and Sopory, S.K. (2006) Role of DREB transcription factors in abiotic and biotic stress tolerance in plants. Plant Cell Reports, 25,1263-1274.

Almodares, A. and Hadi, M.N. (2009) Production of bioethanol from sweet sorghum A review. African Journal of Agricultural Research, 4 (9),772-780.

Aly, M.H., Kamel, A.M. and Hassan, S. (2008) The usage of biofertilizer to minimize the mineral fertilizer for sweet sorghum. Egyptian Journal of Applied Sciences, $\mathbf{2 3}$ (2B),486-499.

Araus, J.L., Slafer, G.A., Reynolds, M.P. and Royo, C. (2002) Plant breeding and drought in $\mathrm{C}_{3}$ cereals: what should we breed for? Annals of Botany, 89, 925-940.

Beck, E.H., Fettig, S., Knake, C., Hartig, K. and Bhattarai, T. (2007) Specific and unspecific responses of plants to cold and drought stress. Journal of Biosciences, 32, 501-510.

Bekheet, M.A., Abdullah, S.S. and Ismail, A.E. (2006) Effects of plant density and weed control on sweet sorghum sugar, forage yields and associated weeds. Assiut Journal of Agricultural Sciences, 37 (1), 21-40. 
Benlhabib, O., Yazar, A., Qadir, M., Lourenco, E. and Jacobsen, S.E. (2014) How can we improve Mediterranean cropping systems? Journal of Agronomy and Crop Science, 200, 325-332.

Black, C.A., Evans, D.D., Ensminger, L.E., White, L.L. and Clark, E. (1965) "Methods of Soil Analysis". Amer. Soc. Agron. Inc., Pub., Madison, Wisc., USA.

Cattivelli, L., Rizza, F., Badeck, F.W., Mazzucotelli, F., Mastrangelo, A.M., Francia, E., Mare, C., Tondelli, A. and Stanca, A.M. (2008) Drought tolerance improvement in crop plants: An integrative view from breeding to genomics. Field Crops Research,105, 1-14.

Dahnke, W.C. and Whitney, D.A. (1988) Measurement of soil salinity. In: "Recommended Chemical Soil Test Procedures for the North Central Region".W.C. Dahnke (Ed.), pp. 32-34, North Dakota Agric. Exp. Stn. Bull. 499p.

Davila-Gomez, F.J., Chuck-Hernandez, C., Perez-Carrillo, E., Rooney, W.L. and Serna-Saldivar, S.O. (2011) Evaluation of bioethanol production from five different varieties of sweet and forage sorghums (Sorghum bicolor (L.) Moench). Industrial Crops and Products, 33, 611-616.

Dingkuhn, M. and Asch, F. (1999) Phenological responses of Oryza sativa, O. glaberrima and inter-specific rice cultivars on a toposquence in West Africa.Euphytica,110, 109126.

F.A.O. (1976) Conservation: Arid and Semi-Arid Zones. - Conservation Guide $\mathrm{N}^{\circ} 3$, Rome.

Farooq, M., Wahid, A., Kobayashi, N., Fujita, D. and Basra, S.M.A. (2009) Plant drought stress: Effects, mechanisms and management - A review. Agronomy for Sustainable Development, 29, 185-212.

Gutte, A.V., Karanjika, P.N. and Dhamak, A.L. (2008) Effect of plant densities and fertilizer levels on quality of sweet sorghum (Sorghum bicolor L. Moench). Journal of Soils and Crops, 18 (1), 108-111.

Hamid, A. and Nasab, A.D.M. (2001) The effect of various plant densities and N levels on phenology of two medium maturity corn hybrids. Iranian Journal of Agricultural Sciences, 32, 857-874.

Jackson, M.L. (1973) "Soil Chemical Analysis". pp. 61-73. $1^{\text {st }}$ ed. Prentice Hall of India Pvt. Ltd., New Delhi, India..

Kavar, T., Maras, M., Kidric, M., Sustar-Vozlic, J. and Meglic, V. (2007) Identification of genes involved in the response of leaves of Phaseolus vulgaris to drought stress. Molecular Breeding, 21, 159-172.

Keeney, D.R. and Deluca, T.H. (1992) Biomass as an energy source for the mid-western US. American Journal of Alternative Agriculture, 7 (3), 137-144.

Lipinski, E.S. (1978) "Sugar Crops as a Source of Fuels", vol. II. Processing and Conversion, Research Dept. of Energy. Final Report. Battelle Columbus Labs, OH. 
Mahama, G.Y. (2012) Variation among grain sorghum genotypes in response to nitrogen fertilizer. M.Sc. Thesis, Department of Agronomy, College of Agriculture, Kansas State University, Manhatton, Kansas.

Mahmoud, E.A., Ramadan, B.S.H., Bekheet, M.A. and Gomaa, M.A. (2013) Effect of Nitrogen fertilization and plant density on productivity and quality of sweet sorghum. American-Eurasia Journal of Agricultural \& Environmental Sciences, 13 (5), 654-659.

Mekdad, A.A.A. and Rady, M.M. (2016) Response of Beta vulgaris L. to nitrogen and micronutrients in dry environment. Plant, Soil and Environment, 62 (1), 23-29.

Mohamed, K.E., Ferweez, H. and Allam, S.M. (2006) Effect of K fertilization on yield and quality of sweet sorghum juice and syrup. Bulletin of Faculty of Agriculture, Cairo University, 57, 401-416.

Mokadem, S.H.A. (1994) Effect of plant population on some sweet sorghum varieties. Minia Journal of Agricultural Research and Development, 16 (3),637-649.

Morris, J.B. (2006) "Production of Sweet Sorghum for Syrup in Kentucky". University of Kentucky Cooperative Extension Service, Publication No. 122, p.6.

Reddy, B.V.S., Ashok Kumar, A. and Ramesh, S. (2007) Sweet sorghum: A water saving bio-energy crop. International Conference on Linkages between Energy and Water Management for Agriculture in Developing Countries. January 29-30, 2007. IWMI, ICRISAT Campus, Hyderabad, India.

Sandeep, R.G., GururajaRao, M.R., VenkateshBhat, B., Rao, S.S., Kulkarnil, R.S., Hittalmani, S. and Srinivasa Murthy, C.A. (2011) Inter-relationship between sugar yield and its component characters in two segregation populations of sweet sorghum [Sorghum bicolor (L.) Moench.]. Electronic Journal of Plant Breeding,2 (2), 244 247.

Sandquist, D.R. and Ehleringer, J.R. (2003) Population- and family-level variation of brittlebush (Encelia farinosa, Asteraceae) pubescence: itsrelation to drought and implications for selection in variable environments. American Journal of Botany, 90, $1481-1486$.

Silva, P.R.F., Argenta, G.Da. and Rezera, F. (1999) Reposta de h'ibridos de milho `a densidade de plantas, emtr^es 'epocas de semeadura [Response of irrigated Corn hybrids to plant density in three sowing dates]. Brazilian Journal of Agricultural Research, 34, 585-592.

Singh, D., Saini, S.K. and Sinha, S.K. (2008) Performance of sugarcane genotypes under different fertility levels. In: Proceedings of the National Seminar on Varietal Planning for Improving Productivity and Sugar Recovery in Sugarcane, held at G.B.P.U.A. \& T. Pantnagar, 14-15 February 2008, pp.240-241.

Subbarao, G.V., Johansen, C., Slinkard, A.E., Rao, R.C.N., Saxena, N.P. and Chauhan, Y.S. (1995) Strategies and scope for improving drought resistance in grain legumes. Critical Reviews in Plant Sciences, 14, 469-523. 
Ture, S., Uzun, D. and Ture, I.E. (1997) The potential use of sweet sorghum as a nonpolluting source of energy. Energy, 22, 17-19.

Turner, N.C., Wright, G.C. and Siddique, K.H.M. (2001) Adaptation of grain legumes (pulses) to water-limited environments. Advances in Agronomy, 71, 123-231.

Vanderlip, R.L. and Reeves, H.E. (1972) [Sorghum bicolor (L.) Moench.] Growth stages of sorghum. Agronomy Journal, 64, 13-16.

Wang, Y., Zhang, X., Zhang, X., Shao, L., Chen, S. and Liu, X. (2016) Soil water regime affecting correlation of carbon iIsotope discrimination with yield and wateruse efficiency of winter wheat. Crop Science, 56, 760-772.

(Received 22/10/2016;

accepted 24/1/2017) 


\title{
إستجابة الإتتاجية للكثافة النباتية في خمس أصناف من الذرة

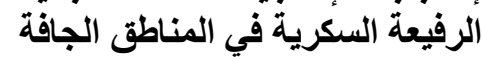

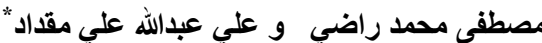

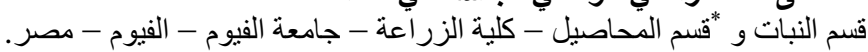

تتصف أراضي المناطق الجافة، كما في مصر بنقص الخصوبة وفقر التركيب

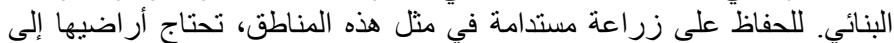

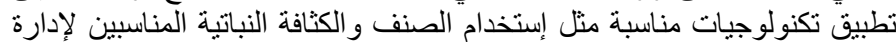

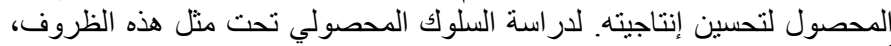

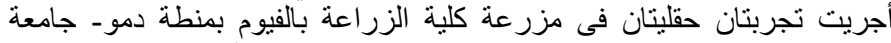

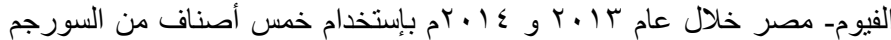

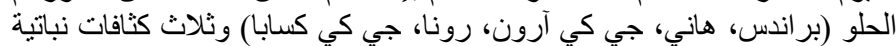

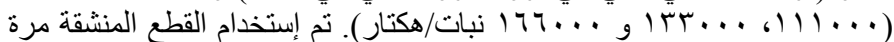

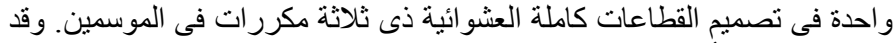

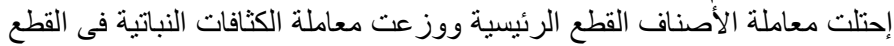

الثقية.

أشارت النتائج إلى إختلافات معنوية بين كل الأصناف في كل القياسات

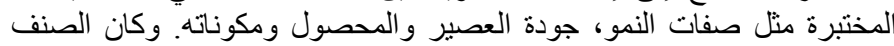

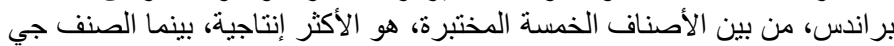

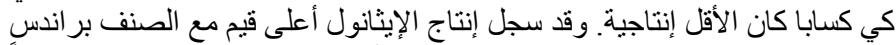

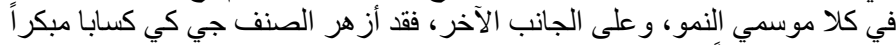

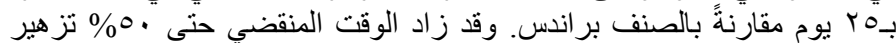

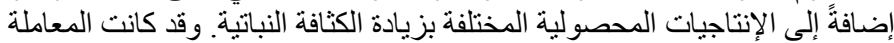

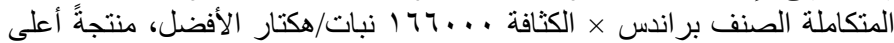

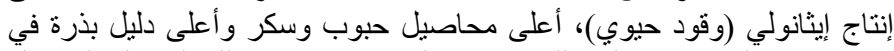

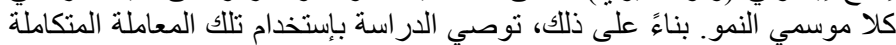

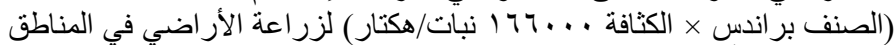

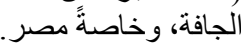

